\title{
STRATEGI PENGEMBANGAN KURIKULUM YANG RELEVAN DENGAN PANGSA PASAR KERJA
}

\author{
M. Syarif \\ Universitas Islam Majapahit, Mojokerto
}

\begin{abstract}
ABSTRAK
Tulisan ini memberikan uraian analisis terhadap kurikulum pendidikan Indonesia yang hingga saat ini masih juga belum mampu memecahkan problema ilmu pengetahuan yang diajarkan di lembaga pendidikan dengan kebutuhan pasar terkait tenaga kerja. la mencoba menawarkan alternatif terhadap beberapa hal yang paling diperlukan bagi peningkatan mutu lulusan lembaga pendidikan terutama dari aspek meningkatkan manajemen peserta didik, meningkatkan relevansi kurikulum dengan kebutuhan pasar dan optimalisasi peran stake holder dalam dunia kerja agar bias bersinergi dengan usaha usaha pendidikaan di Indonesia.

Kata Kunci: Pengembangan Kurikulum, Pangsa Pasar Kerja.
\end{abstract}

\section{A. Pendahuluan}

Ada satu diskusi yang kecil di group jejaring sosial Facebook dalam mensikapi pengangkatan Susi Pudjiastuti sebagai Menteri Kelautan dan Perikanan dalam Kabinet Kerja Presiden dan Wakil Presiden Republik Indonesia, Jokowi-JK. Pengangkatan Susi menjadi pro dan kontra di masyarakat, khususnya di dunia maya bukan hanya disebabkan karena gayanya yang terkesan eksentrik sebagai seorang perempuan dan seorang menteri karena kebiasaan merokok dan tatonya, namun lebih dari itu, Susi sendiri yang merupakan Lulusan SMP dapat menjadi pengusaha dan menteri walaupun tidak tamat 
SMA. ${ }^{1}$ Dalam berbagai perspektif, hal tersebut menjadi suatu fenomena yang memancing berbagai tanggapan, termasuk dalam berbagai diskusi di Media sosial.

Perdebatan kecil di atas sesungguhnya menarik untuk dicermati. Namun ada yang perlu digaris bawahi sebagai tanggapan terhadap perdebatan di atas, yaitu pertama: bahwa ijazah yang dikeluarkan oleh lembaga pendidikan di Indonesia sulit diterima di luar negeri, bahkan cenderung diremehkan, hal itu dikarenakan ijazah tersebut tidak benar-benar menyimbolkan kemampuan pemiliknya, dalam konteks ini, ijazah seharusnya tidak hanya merupakan sebuah Surat Tanda Tamat Belajar (STTB) yang diperoleh siswa setelah melalui kegiatan-kegiatan di sekolah dalam rentang waktu tertentu. ljazah seharusnya merupkan sebuah bukti kepemilikan pengetahuan, ketrampilan dan sikap-sikap yang dapat diukur secara jelas.

Kedua, Persoalan ijazah tersebut bukanlah persoalan kasuistik, namun merupakan persoalan nasional, untuk itu pemerintah telah memperhatikan masalah tersebut dan melalui menteri pendidikan dan kebudayaan mengeluarkan Permendikbud No 7 Th. 2013 tentang Pedoman Penataan Pegawai Berbasis Kompetensi di Lingkungan Kementrian Penididkan dan Kebudayaan bersama 7 lampirannya, No 49 Th. 2014 tentang Standart Nasional Pendidikan Tinggi, dan juga No 81/2014 tentang ljazah, Sertifikat Kompetensi dan Sertifikat Profesi.

Ketiga, Menyimak persoalan yang diperdebatkan di atas, yang patut dijadikan perhatian para Pengelola Pendidikan sebenarnya bukan hanya masalah ijazah, karena substansi persoalannya adalah bagaimana Lulusan lembaga pendidikan dapat diserap oleh pangsa pasar kerja secara mudah, karena kenyataannya, penyerapan tenaga kerja yang berasal dari Lulusan Pendidikan Tinggi masih kecil.

${ }^{1}$ Doddy Rosady, Sepenggal Kisah Kehidupan Menteri yang Eksentrik. www.suara.com: 29 Oktober 2014. 
Menanggapi masih kecilnya penyerapan Lulusan Pendidikan Tinggi dalam pangsa pasar kerja serta bayaknya jumlah pengangguran yang berpendidikan universitas, maka setiap orang bisa saja menganggap bahwa hal itu karena ilmunya "tidak manfaat". Orang boleh saja beranggapan demikian, namun yang pasti, problem banyaknya Lulusan yang tidak segera memasuki lapangan kerja yang menjanjikan pendapatan cukup, memunculkan kritik, bahwa pendidikan telah melahirkan "Pengangguran Terpelajar," "Pengangguran Intelektual," dan semacamnya.

Terkait dengan fenomena tersebut, maka sejatinya terdapat 2 persoalan besar, yaitu: pertama, Lulusan Pendidikan tidak mendapatkan kerja karena memang tidak adanya lapangan pekerjaan yang sesuai, dan yang kedua, Lulusan memang tidak berkompeten untuk memasuki pekerjaan yang ada. Bila diringkas, ke 2 persoalan tersebut sesungguhnya bermuara pada persoalan relevansi kurikulum/program pendidikan dengan kebutuhan Peserta Didik/masyarakat serta kemampuannya dalam membekali Peserta Didik yang berkompeten sesuai tuntutan pangsa pasar kerja.

Berdasarkan latar belakang masalah di atas, permasalahan yang menjadi fokus kajian tulisan ini adalah kecilnya penyerapan tenaga kerja yang berasal dari Lulusan Pendidikan Tinggi dan sebaliknya "pengangguran intelektual" yang besar. Permasalahan tersebut diantaranya disebabkan oleh 2 hal: pertama, Lulusan Pendidikan Tinggi tidak mendapatkan kerja karena tidak adanya lapangan kerja yang sesuai. kedua, Lulusan Pendidikan Tinggi tidak berkompeten untuk memasuki pekerjaan yang ada.

Jika dianalisa dalam perspektif pengembangan kurikulum, lahirnya 2 persoalan tersebut erat kaitannya dengan relevansi kurikulum dalam memenuhi kebutuhan masyarakat dan kompetensi Peserta Didik yang sesuai dengan tuntutan pangsa pasar kerja. 


\section{B. Konsep Pengembangan Kurikulum}

Untuk menjamin agar implementasi kurikulum dapat mewujudkan tercapainya tujuan pendidikan yang relevan dengan tuntutan stake holder dan kebutuhan Peserta Didik, maka kurikulum harus dapat dikembangkan secara berkelanjutan. Oleh karena itu Menurut Dzakir, Pengembangan kurikulum pada dasarnya adalah upaya mengarahkan kurikulum yang ada ke tujuan pendidikan yang diharapkan karena adanya pengaruh positif dari luar atau dari dalam lembaga pendidikan dengan harapan agar Peserta Didik dapat menghadapi masa depan yang lebih baik. ${ }^{2}$ Sementara itu Muhaimin pada prinsipnya mengartikan pengmebangan kurikulum sebagai kegiatan penyusunan (desain), pelaksanaan, penilaian dan penyempurnaan kurikulum. $^{3}$ Pengembangan kurikulum dapat dilakukan dengan mengikuti beberapa pendekatan, diantaranya:

1. Pendekatan Subjek Akademis, yaitu pendekatan yang didasarkan pada pada sistematisasi disiplin ilmu masing-masing yang berbeda antara satu disiplin ilmu dengan disiplin ilmu lainnya.

2. Pendekatan Humanistis, yaitu pendekatan yang didasarkan pada ide memanusiakan manusia. Pendekatan kurikulum ini diharapkan dapat menciptakan konteks yang akan memberi peluang manusia untuk menjadi lebih human/untuk memprtinggi harkat manusia. Dalam model ini, kurikulum dikembangkan dengan bertolak pada kebutuhan dan minat Peserta Didik, oleh karena itu, tujuan program pendidikan adalah untuk mendorong Peserta Didik dapat menumbuhkan kembangkan potensi dasar dan instrumentinstrumennya. Proses pengembangan dilakukan dengan cara melibatkan Peserta Didik, misalnya dalam penentuan tujuan dan pemilihan materi pembelajaran.

\footnotetext{
${ }^{2}$ Dakir, Perencanaan dan Pengembangan Kurikulum (Jakarta: Reineka Cipta, 2010 ), 84. ${ }^{3}$ Muhaimin, Pengembangan Kurikulum Pendidikan Agama Islam di Sekolah, Madrasah dan Perguruan Tinggi (Jakarta: PT Raja Grafino Persada, 2005), hlm. 10
} 
3. Pendekatan teknologis, yaitu yang bertolak dari analisis kompetensi yang dibutuhkan untuk melaksanakan tugas-tugas tertentu. Untuk itu, materi yang diajarkan, kriteria evaluasi sukses dan strategi pembelajarannya ditetapkan sesuai dengan analisis tugas tersebut.

4. Pendekatan rekonstruksi sosial dalam menyusun kurikulum bertolak dari problem yang dihadapi masyarakat untuk selanjutnya dengan memerankan ilmu dan teknologi serta bekrja secara kooperatif dan kolaboratif untuk mencai upaya pemecahannya menuju pembentukan masyarakat yang lebih baik.

5. Pendekatan Pendidikan Berbasis Luaran (PBL) dalam menyusun kurikulum bersifat lintas sektoral. Hal ini menggambarkan keterpaduan kurikulum PBL yang bersifat kontekstual, baik dalam aspek pembelajaran maupun aspek fenomena yang dipelajari oleh para mahasiswa. Salah satu ciri dari kurikulum PBL adalah adanya apsek profesional yang sejak awal telah dikenalkan kepada permasalahan profesi yang kelak akan dijalaninya. ${ }^{4}$

Adapun langkah-langkah pengembangan kurikulum dapat menggunakan model-model sebagai berikut:

1. Model administrative atau model garis staf atau top down. Langkahlangkahnya adalah : 1) atasan membentuk tim yang berwenang, 2) tim merencanakan konsep rumusan tujuan umum dan falsafah yang diikuti, 3) dibentuk beberapa kelompok kerja yang anggotanya adalah para spesialis kurikulum dan staf pengajar yang bertugas untuk merumuskan tujuan khusus, GBPP dan kegiatan belajar, 4) dilakukan revisi, 5) implementasi.

2. Model dari bawah atau grass-roats, langkah-langkahnya adalah: 1) staf pengajar menemukan sutau ide, 2) menyusun tim yang terdiri dari pengajar lembaga lain, nara sumber, orangtua atau

\footnotetext{
${ }^{4}$ Sudarwan Danim, Visi Baru Manajemen Sekolah; dari Unit Birokrsi ke Lembaga Akademik (Jakarta: Bumi Aksara, 1997) 68.
} 
masyarakat, 3) atasan memberikan bimbingan dan dorongan, 4) dilakukan lokakarya untuk mencari input yang diperlukan.

3. Model demontrasi, langkah-langkahnya: 1) staf pengajar menemukan ide pengembangan yang dinilai baik, 2) hasilnya disebarluaskan.

4. Model beaucham, langkah-langkahnya adalah: 1) disusun pengembangan yang dilaksanakan di kelas untuk diperluas di tingkat lembaga sendiri dan lembaga lain baik tingkat regional maupun nasional, 2) menunjuk tim pengembang untuk menyusun komponen kurikulum, 3) pelaksanaan dan 4) valuasi.

5. Model terbalik Hilda Taba, langkah-langkahnya adalah: 1) mendiagnosis kebutuhan, merumuskan tujuan, menentukan materi, penilaian, memperhatikan luas dalamnya bahan kemudian disusun unit suatu kurikulum, 2) mengadakan tryout, 3) mengadakan revisi atas dasar try out. 4) menyusun kerangka kerja teori, 5) mengemukakan adanya kurikulum baru yang akan diseminasikan.

6. Model hubungan interpersonal Rogers, langkah-langkahnya adalah: 1) diadakan diskusi kelompok untuk mmperoleh hubungan interpersonal, 2) peserta kelompok mengadakan saling tukar pengalaman dibawah pimpinan staf pengajar, 3) mengadakan pertemuan dengan masyarakat yang lebih luas untuk menjalin hubungan interpersonal yang lebih sempurna antara guru dengan guru, Peserta Didik dengan Peserta Didik dalam suasana yang akarab, 4) mengadakan pertemuan dengan berbagai komponen pendidikan untuk memudahkan pemecahan berbagai persoalan pendidikan.

7. Model action research yang sistematis, langkah-langkahnya adalah: 1) dirasa adanya problem proses belajar mengajar disekolah yang perlu diteliti, 2) mencari sebab-sebab terjadinya problem dan sekaligus dicari pemecahannya. Kemudian menentukan putusan 
apa yang perlu diambil seubungan dengan masalah yang ada tersebut, 3) melaksanakan putusan yang diambil. ${ }^{5}$

$\mathrm{Di}$ antara poin penting yang terdapat dalam model-model pengembangan kurikulum tersebut khususnya dalam model Administrative, Grass-roats atau model Beaucham, untuk pengembangan kurikulum yang relevan dengan tuntutan stake holder dan kebutuhan Peserta Didik, adalah diikutsertakannya stake holder/masyarakat dalam penyusunan kurikulum pendidikan.

Selain model-model di atas, proses pengembangan kurikulum yang sederhana dapat dilakukan melalui 3 tahap yaitu : perencanaan, implementasi dan evaluasi. ${ }^{6}$ Perencanaan dilakuakn dengan cara mengakomodasi dari ide-ide yang akan dituangkan dan dikembangkan dalam program. Ide itu sendiri dapat berasal dari visi, kebutuhan stake holder, hasil evaluasi kurikulum sebelumnya dengan tuntutan perkembangan ipteks dan zaman, pandangan para pakar dengan berbagai latar belakangnya, maupun dengan kecenderungan era globaisasi yang menuntut seseorang yang memiliki etos belajar sepanjang hayat, melek social, ekonomi, politik, budaya dan tekhnologi.

Pada tahap pelaksanaan, ide-ide di atas kemudian diramu sedemikian rupa untuk dikembangkan dalam kurikulum sebagai dokumen yang disosialisasikan pelaksanaannya dalam bentuk perencanaan pembelajaran, proses belajar mengajar dan evaluasiya, untuk mengetahui efetifitas dan efisiensinya. Evaluasi tersebut dilakukan untuk memperoleh umpan balik yang akan digunakan dalam penyempurnaan kurikulum berikutnya.

Model-model pendekatan kurikulum beserta proses-proses pengembangannya tentu saja mengandung keterbatasanketerbatasan. Untuk itu perlu strategi tertentu agar kurikulum yang

${ }^{5}$ Dzakir, Op.Cid. 56

${ }^{6}$ Muhamin, Op.Cid., 12 - 13 
akan diimplementasikan relevan dengan pangsa pasar kerja. Dengan upaya tersebut diharapkan Lulusan dapat dengan mudah terserap dalam dunia kerja yang menjadi indicator bahwa ilmu yang dimiliki oleh Lulusan adalah ilmu yang bermanfaat dan dimanfaatkan.

\section{Strategi Pengembangan Kurikulum yang Relevan dengan Pangsa Pasar Kerja}

Jika pemikiran bahwa ilmu yang manfaat adalah ilmu yang dimanfaatkan sebagaimana rekomendasi tulisan ini dapat diterima, maka konsekwensi logisnya, penyerapan Lulusan ke dalam pangsa pasar kerja tidak hanya menjadi tanggung jawab pribadi Lulusan melainkan juga menjadi tanggung jawab Pendidik, Pengelola Pendidikan dan juga Stake Holder. Adapun untuk merealisasikan tanggung jawab tersebut secara optimal, maka Pengelola Pendidikan harus mampu mengembangkan sistem manajemen yang lebih efektif, baik dalam konteks manajemen Peserta Didik, manajemen kelembagaan maupun manajemen kurikulum.

Dalam konteks manajemen Peserta Didik, para Pengelola Pendidikan harus dapat menerapkan manajemen Peserta Didik yang lebih menyeluruh, tidak hanya dalam proses penerimaan Peserta Didik baru dan proses pembelajaran semata, tetapi juga dalam proses persiapan studi lanjut atau bekerja. Untuk itu, dalam perencanaanya, lembaga pendidikan sejak awal harus sudah memiliki program yang menyiapkan Peserta Didik agar setelah lulus mudah terserap dalam pangsa pasar kerja. Program tersebut telah disiapkan sejak sebelum Peserta Didik memasuki lembaga pendidikan baru dan akan ditindak lanjuti dalam kurikulum atau program pendidikan secara riil, jelas serta dapat dibuktikan.

Sistem manajemen Peserta Didik yang demikian itu memang agak kurang biasa dilakukan, bahkan selama ini seolah-olah tanggung jawab Pendidik dan atau Pengelola Pendidikan hanya memberikan 
program dan layanan pendidikan yang berkualitas. Adapun bagaimana nasib Peserta Didik setelah menamatkan proses pendidikannya, seolah-olah hal itu bukan merupakan tanggung jawab pendidik dan atau Pengelola Pendidikan, terlebih lagi stake holder, mereka sama sekali terlepas dari tanggung jawab terhadap nasib lulusan setelah mereka menamatkan proses pendidikannya.

Kenyataan lepasnya tanggung jawab terhadap lulusan setelah mereka menamatkan proses pendidikannya, sesungguhnya merupakan tradisi yang tidak tepat karena menurut Mujamil Qomar, manajemen Peserta Didik pada dasarnya terdiri dari 3 tahap, yaitu: tahap penjaringan, tahap pemrosesan dan tahap pendistribusian. ${ }^{7}$

Sejalan dengan pemikiran Mujamil Qomar di atas, perlu ditegaskan kembali bahwa tanggung jawab Pengelola Pendidikan tidak hanya memberikan program dan layanan pendidikan yang berkualitas saja, tetapi juga ikut membantu mengupayakan penyerapan dan distribusi Peserta Didik ke dalam lapangan kerja. Untuk dapat merealisasikan hal tersebut maka dalam manajemen kelembagaan ada 2 hal yang dapat dilakukan oleh lembaga pendidikan, yaitu 1) menciptakan lapangan kerja yang seluas-luasnya bagi Peserta Didik dengan cara membangun perusahaan atau instansi kerja yang sesuai dengan pendidikan Peserta Didik, misalnya jika Pendidikan Tinggi memiliki program studi Tekhnologi Hasil Pertanian, maka semestinya Perguruan Tinggi juga memiliki Industri Pengolahan Pangan yang Pengelola dan Pegawainya berasal dari lulusan prodi tersebut, kemudian untuk menjual produknya, Perguruan Tinggi juga perlu mendirikan "pasar" yang dikelola oleh Manajer dan Pegawai yang berasal lulusan Fakultas Ekonomi.

Begitupun misalnya, Perguruan Tinggi memiliki Program Studi Kependidikan, baik Pendidikan Agama Islam maupun mmum, maka

\footnotetext{
${ }^{7}$ Mujamil Qomar, Manajemen Pendidikan Islam; Strategi Baru Pengelolaan Pendidikan Islam (Jakarta : Erlangga, 2007) 142.
} 
seharusnya Perguruan Tinggi juga membangun sekolah/madrasah yang dapat menampung pendidik dan tenaga kependidikan yang berasal dari Lulusan Program Studi tersebut.

Agar dapat berkembang secara optimal, maka baik industri Pengolahan Pangan beserta "pasar" penjualan produknya, termasuk juga lembaga pendidikan baik sekolah maupun madrasah, dan lainlainnya, semuanya harus dikelola secara professional dan menjadi mitra kerja yang saling menguntungkan bagi program studi dalam pelaksanaan Tri Dharma Perguruan Tinggi.

Dalam konteks pengembangan kurikulum, industry, pasar, instansi kerja dan lain-lain tersebut selanjutnya dapat dijadikan sebagi laboratorium pengembangan kurikulum pendidikan, dimana teori-teori yang ada akan dipelajari, diuji, diterapkan, dan dikembangkan melalui proses penelitian yang efektif.

Lebih jauh, apa yang harus dilakukan oleh Pengelola Pendidikan adalah membangun jaringan kerjasama dan ikatan dinas dengan perusahaan dan instansi terkait yang terdapat di luar kampus, kemudian untuk mempererat kerjasama tersebut, maka pada saat wisuda kegiatan seremonial yang penting diperguruan tinggi, para pengusaha dan pemimpin instansi tersebut bisa diundang, agar Pimpinan Universitas dapat mempromosikan para wisudawan dan prestasi-prestasinya kepada mereka, sehingga dengan begitu, para pengusaha atau pimpinan terkait dapat mengakses para Lulusan yang ingin bekerja sesuai dengan keahliannya masing-masing.

\section{Penutup}

Sebagai bagian akhir yang menutup tulisan ini, maka ada beberapa hal yang perlu ditegaskan kembali sebagai kesimpulan, yaitu bahwa konsep ilmu yang manfaat perlu digeser pengertiannya menjadi ilmu yang dimanfaatkan, dalam arti diupayakan kemanfaatannya oleh Pengelola Pendidikan dan stake holder. 
Upaya memanfaatkan ilmu yang dimaksud dalam tulisan ini merupakan bagian dari tanggung jawab Pengelola Pendidikan dan stake holder dalam menyelesaikan problem "pengangguran intekektual" yang muncul karena persoalan relevansi kurikulum dengan tuntutan pangsa pasar kerja. Adapun strategi pengembangan kurikulum yang relevan dengan pangsa pasar kerja yang direkomendasikan dalam tulisan ini adalah:

1. Menerapkan manajemen Peserta Didik secara menyeluruh, tidak hanya dalam proses penerimaan Peserta Didik baru dan proses pembelajaran semata, tetapi juga dalam proses persiapan studi lanjut atau bekerja.

2. Menciptakan lapangan kerja seluas-luasnya bagi Peserta Didik atau membangun jaringan kerjasama dan ikatan dinas dengan para pengusaha atau pemimpin instansi terkait dan menjadi penghubung langsung antara lulusan dengan pangsa kerja agar penyerapan dan pendistribusian Peserta Didik ke dalam lapangan kerja yang sesuai semakin mudah dilakukan.

3. Meningkatkan relevansi kurikulum dengan kebutuhan masyarakat dan kompetensi Peserta Didik yang sesuai tuntutan dunia kerja dengan cara melakukan peninjauan, pengembangan, implementasi dan standarisasi kurikulum scara konsisten dan berkelanjutan.

4. Optimalisasi peran Stake Holder dari pihak perusahaan dan instansi terkait dengan cara melibatkan mereka untuk membantu mengembangkan acuan dasar yang mendukung relevansi kurikulum dengan pangsa pasar kerja dan merumuskan parameter proses yang dikehendaki, melakukan peninjauan kurikulum dan dokumen pelaksanaannya, evaluasi prosedur dan membuat perubahan jika dibutuhkan untuk menjamin keberhasilan program penddikan, serta membantu menemukan cara untuk menyediakan sumber-sumber, pelatihan dan dukungan bagi lembaga pendidikan.

5. Menyusun kurikulum yang dapat membantu Peserta Didik 
mendemonstrasikan capaian pembelajaran di dalam sistem yang menjamin mereka menguasai pengetahuan dan ketrampilan yang sesuai persyaratan pangsa pasar kerja secara nyata.

Agar kurikulum tersebut ini dapat mencapai target yang diinginkan, maka revitalisasi kinerja Pengelola Pendidikan, Pendidik dan Peserta Didik akan menjadi sesuatu yang tidak mungkin dapat dihindarkan, terlebih lagi bagi seorang pendidik yang merupakan garda terdepan dalam implementasi kurikulum. Pendidik harus menjadi perhatian penting karena yang berhadapan langsung dengan Peserta Didik dan memberikan pengaruh langsung terhadap keberhasilan mereka dalam proses pendidikan. ${ }^{8}$

Strategi dan bentuk kurikulum yang direkomendasikan tulisan ini dapat dianggap sebagai sebuah inovasi, dan perlu disadari, bahwa inovasi tersebut belum banyak dilakukan oleh Pengelola Pendidikan Tinggi karena adanya berbagai keterbatasan. Selain itu, tidaklah mudah mengubah kebiasaan lama kepada kebiasaan yang baru, terlebih lagi jika mind set-nya belum berubah. Namun, hal itu bukan berarti bahwa upaya yang direkomendasikan dalam tulisan ini tidak realistis, karena upaya yang direkomendasikan tersebut sesungguhnya bukan tidak bisa dilakukan, tetapi lebih karena tidak mampu dilakukan, karenanya diperlukan waktu dan persiapan yang cukup, serta komitmen yang besar agar apa yang diinginkan dapat tercapai.

Kalaupun pada kenyataannya manajemen pendidikan mempunyai beberapa keterbatasan yang menghambat upaya tersebut, maka tidak seharusnya hal itu menjadi halangan untuk merealisasikan tanggung jawab untuk meningkatkan relevansi kurikulum dengan pangsa pasar kerja yang selalu dtuntut pertanggung jawabannya, tidak hanya sebagai Pendidik atau Pengelola Pendidikan professional,

\footnotetext{
${ }^{8}$ Faridah Alawiyah, Kesiapan Guru dalam Implementasi Kurikulum 2013. Jurnal "Info Singkat; Kajian Singkat Terhadap Isu-Isu Terkini”. Vol. VI, No. 15-I/Agustus/2014. (Jakarta : Pusat Pengkajian, Pengolahan Data dan Informasi (P3DI) Sekretariat Jenderal DPR RI, 20014) 10.
} 
namun juga sebagai manusia yang harus bertanggung jawab terhadap agama dan peri kemanusiaan.

\section{DAFTAR PUSTAKA}

Ardyan Muhammad, Organisasi Kerjasama Ekonomi dan Pengembangan (OECD): Sarjana Indonesia Terbanyak Ke 5 Di Dunia. Merdeka.com. Jumat, 13 Juli 2012

Badan Pusat Statistik, Berita Remi Berita Resmi Statistik Tentang Keadaan Ketenagakerjaan Februari 2014 no. 38/05/th. xvii, 5 mei 2014. www.bps.go.id.

Dakir, Perencanaan dan Pengembangan Kurikulum (Jakarta: Reineka Cipta, 2010)

Departemen Pendidikan Nasional Republik Indonesia. Keputusan Menteri Pendidikan Nasional nomor 232/U/2000 tentang Pedoman Penyusunan Kurikulum Pendidikan Tinggi dan Penilaian Hasil Belajar Mahasiswa. Jakarta, 2000

Doddy Rosady, Sepenggal Kisah Kehidupan Menteri yang Eksentrik. www.suara.com: 29 Oktober 2014.

Faridah Alawiyah, Kesiapan Guru dalam Implementasi Kurikulum 2013. Dalam Jurnal "Info Singkat; Kajian Singkat Terhadap Isu-Isu Terkini". Vol. VI, No. 15-I/Agustus/2014. (Jakarta : Pusat Pengkajian, Pengolahan Data dan Informasi (P3DI) Sekretariat Jenderal DPR RI, 20014

Harsono, Pengembangan Kurikulum di Perguruan Tinggi, makalah dipresentasikan pada lokakarya kurikulum Universitas Negeri Semarang, 20-21 September 2006, direvisi tanggal 2 Februari 2007.

Imam Bawani, Kebijakan Pendidikan di Era Globalisasi; Perpsektif dan Kebijakan Pendidikan Menghadapi Tantangan Global. Jurnal Tadzkirah Universitas Pesantren Tinggi Darul Ulum Jombang, Volume 5 Tahun 5 Agustus 2010

Lembaran Negara Republik Indonesia Nomor 78. Undang-undang Republik Indonesia Nomor 20 tahun 2003 tentang Sistem Pendidikan Nasional; 2003. 
Muhaimin, Pengembangan Kurikulum Pendidikan Agama Islam di Sekolah, Madrasah dan Perguruan Tinggi (Jakarta: PT Raja Grafino Persada, 2005)

Muhammad Anwar (tt.), Pengembangan Kurikulum dari Materi Pelajaran Kepengalaman Belajar. Jurnal IImu Pendidikan. Lembaga Pendidikan Tenaga Kependidikan (IPTK) dan Ikatan Sarjana Pendidikan Indonesia (ISPI).

Mujamil Qomar, Manajemen Pendidikan Islam; Strategi Baru Pengelolaan Pendidikan Islam (Jakarta : Erlangga, 2007)

Murni Eva Marlina, Kurikulum 2013 yang Berkarakter, Jurnal Program Studi Pendidikan Antropologi, FIS - UNIMED "JUPIIS", Volume 5 Nomor 2, Desember 2013, hlm. 30.

Murni Eva Marlina, Kurikulum 2013 yang Berkarakter, Jurnal Program Studi Pendidikan Antropologi, FIS - UNIMED "JUPIIS", Volume 5 Nomor 2, Desember 2013

Nana Syodih Sukamadinata, Pengembangan Kurikulum, Teori dan Praktik (Bandung: Remaja Rosdakarya, 2005)

Sariono, Kurikulum 2013: Kurikulum Generasi Emas. E-jurnal Dinas Pendidikan Kota Surabaya; Volume 3 Tahun 2014.

Sudarwan Danim, Visi Baru Manajemen Sekolah; dari Unit Birokrsi ke Lembaga Akademik (Jakarta: Bumi Aksara, 1997)

Tutang, Penghasilan Tenaga IT. www.ristek.go.id. 14 mei 2013 